\title{
CAMEL As A Mathod Used For Assessing The Performance
}

\author{
Gede Putu Agus Jana Susila ${ }^{{ }^{*}}$ \\ ${ }^{1}$ Ganesha University of Education, Singaraja, Indonesia
}

\begin{abstract}
As the role played by the Village Credit Union hereinafter referred to as Lembaga Perkreditan Desa (LPD) in the economic development of the rural society is important, the result of its performance in the form of the adequate financial statement should be presented to make people trust its existence. This present study is intended to identify how healthy the LPD Units in Gerokgak District, Buleleng Regency are using the CAMEL method for the period 2015-2016. The aspects used to assess how healthy the LPD is are as follows: (1) Capital with one ratio, namely $C A R$, (2) Assets with two ratios, KAP and CPRR, (3) Management, (4) Earnings with two ratios, namely $R O A$ and $B O P O$, and (5) Liquidity with two ratios, namely liquid instrument and LDR. The LPD could fulfill the criterion of being healthy as the average CAMEL credit value achieved was higher than 81 (the minimum limit of being healthy). Based on the analysis of how healthy the LPD from 2015 to 2016 were, it can be concluded that: (1) The CAMEL credit value achieved in 2015 was 86.48 points. (2) In 2016, the fact that the CAMEL credit value achieved in 2016 was 88.72 points.
\end{abstract}

Keywords: CAMEL, Village Credit Union (LPD)

\section{INTRODUCTION}

Bali is one of the provinces in Indonesia which is well-known for its culture. What is unique in Bali is the existence of the traditional village 'desa pakraman'. The roles it play are not only limited to the social, cultural and religious roles but they also include its economic role. LPD is one of the credit unions which the traditional village has. It functions and is intended to contribute to the village economic development through the directed saving and the effective distribution of capital. Its existence is regulated in the Regional Regulation 'Peraturan Daerah' Number 3 of 2007. It is derived from the Regional Regulation of Bali Province Number 3 of 2002 'Peraturan Daerah Provinsi Bali Nomor 8 Tahun 2002'. It underlines that LPD is the village-owned financial company which undertakes its business activities within the village and for the villagers.

LPD is the original source of the traditional village's income, as $20 \%$ of the benefit obtained is spent on what is needed for improving the traditional village's empowerment. Its existence in the traditional village has been able to improve its potentials; it has been able to help and alleviate the burden of the traditional village. In addition, it has also significantly contributed to those who are economically weak. In general, its function and goal have been supervised by the Bali Regional Development Bank. Among the LPD units which have been established in Bali, those which have been established at the traditional villages under Gerokgak

* Corresponding author. Email address: Janos_undiksha@yahoo.com 
District are used as the subject of the present study. Added together, there are 13 units spreading at every traditional village in Gerokgak District. They are at Banyupoh traditional village, Gerokgak traditional village, Musi traditional village, Patas traditional village, Pejarakan traditional village, Pemuteran traditional village, Pengulon traditional village, Penyabangan traditional village, Sanggalahit traditional village, Sumberkima traditional village, Tiga-tinga traditional village, Tukad Sumaga traditional village, and Celukan Bawang traditional village.

As the role played by LPD in the economic development for the rural community is important, it needs to be supported with good bookkeeping and administration. It is necessary for it to present the result of its performance in the form of adequate financial statement to strengthen the people's trust in it. The financial statement can give information to the stakeholders and show how healthy it is. In addition, it can also show the result it has achieved. The financial statement is made up of balance sheet, income statement, changes in capital statement, cash flow statement and report on transaction records (Standar Akuntansi Keuangan, 2009). Every LPD Unit is obliged to report the result of what it has done and its development and liquidity every month, and how healthy it is every three months to the Board of Supervisors, the Bali Regional Development Bank, the Supervisor of LPD in the regency level and the village's leaders. In this way, the development of each unit of LPD can be identified.

It is necessary to assess how healthy the LPD Units in Gerokgak District are. The reason is that they are trusted as the credit unions which can save the people's money and distribute credits to people. It is necessary to maintain and assess how healthy they are as there has been a fact that some LPD Units in Buleleng Regency have gone bankrupt. It is also intended to anticipate the economic impact if they are assessed not to be healthy. As well, if the LPD Units in Gerokgak District are assessed to be under the category of being healthy, it can strengthen the people's trust in them. Based on the Bali Governor's Regulation dated 7 March 2013 Number 11 of 2013, the LPD's soundness can be assessed using the CAMEL (Capital, Asset, Management, Earning, Liquidity) method.

According to Ramantha (2014), the LPD's supervisor can assess how healthy a LPD unit is using the capital, asset, management, earning, and liquidity (CAMEL) method. This concept is derived from the international banking regulation well-known as Bank for International Settlements (BIS), which stands for capital, assets, management, earning and liquidity. The LPD's capital can be assessed from the capital ratio of the risk-based productive asset. Capital is one of the highly important things needed to anticipate the risk of loss, the protection of the customer funds and the bad credit risk. Distributing funds to the villagers is the LPD's main activity as it is at the same time the only source of the village's income. The quality of its productive assets is used to measure how healthy it is in regard to the productive assets it has. The focus of the assessment of how healthy it is includes its capital, assets, profitability and the management of its liquidity. The qualitative criterion is given more emphasis. In this criterion, the cooperation it makes in the maintenance of liquidity is assessed. Its ability to obtain earnings is considered important as through profit it can widen the scope of the service it provides to the villagers. How healthy it is can be seen from the side of its liquidity. The LPD's management is required to pay attention to the condition of its capital, assets, and profitability. 


\section{LITERATURE STUDY}

\section{The Village Credit Union 'Lembaga Perkrediatan Desa'}

Initially, the Ministry of Foreign Affairs of the Republic of Indonesia held a seminar on the Rural Credit in Semarang City in February 1984. Based on the decision made in the seminar, the Bali Provincial Government established the first LPD Unit as the pilot project. Based on what is stated in the Regional Regulation Number 2/1988 and Number 8 of 2002 concerning LPD that the establishment of the LPD Unit at every traditional village is intended to support the rural economic development by motivating the villagers to get more accustomed to saving, preparing credits for small-scale businesses, eliminating the forms of exploitation of credits, creating equal business opportunities in the village level, and increasing the level of monetization in the village level.

Based on the Bali Provincial Regulation Number 8 of 2002 article 5, several requirements should be met, namely the traditional village where an LPD Unit will be established should have the written local regulations 'awig-awig' regulating its socio-economic activities, and it is potentially enough to establish a financial statement. The permit of the establishment of an LPD Unit should be recommended by the Regent or Mayor. Then the decision is made by the Governor. How LPD is supervised is different from how a micro financial institution controlled by the government is supervised. Based on the Governor's decree Number 344/1993 article 2 (the Bali Government, 1993), it is stated that the Bali Regional Development Bank 'Bank BPD Bali' has three functions, as far as the existence of LPD is concerned, as follows.

1) Technically supervising LPD, which can be divided into passive supervision and active supervision; the active one is done by directly visiting the traditional village where it is established;

2) The Bali Regional Development Bank 'Bank BPD Bali' is supposed to manage the coordination with the other organizations involved in the process of LPD;

3) The Bali Regional Development Bank "Bank BPD Bali' should prepare the quarterly evaluation report of the financial performance of and how healthy LPD is to the governor.

As far as the organizational structure of LPD is concerned, it is part of what is referred to as 'sekaa' (traditional organization) in which Head of LPD is responsible for its operation and head of the traditional village 'bendesa' is the main supervisor. The villagers are its members and structurally it is made up of different banjars (the neighborhood under the traditional village).

The assessment of how healthy LPD is using the CAMEL method.

Based on the Bali Governor's Regulation dated 7 March 2013 Number 11 of 2013, the indicators used to assess how healthy an LPD is are : (1) Capital, (2) Asset, (3) Management, (4) Earning and (5) Liquidity.

\section{1) Capital}

The assessment is made based on the capital which a bank has. Capital Adequacy Ratio (CAR) is one of the methods used in which the capital is compared to the Risk-weighted Assets 'Aktiva Tertimbang Menurut Risiko (ATMR). CAR is the ratio which shows how risky the whole assets of a bank (credit, accompaniment, securities, claims to other banks). In this case, the assets which are funded from the bank's capital and the funds obtained from the sources outside the bank such as the funds which come from society, loans, and so forth. In other 
words, CAR is the ratio of the bank's performance used to measure whether the capital which the bank has is adequate enough to support the risky assets, for example, the loans provided. According to Kasmir (2002: 185), the CAR ratio can be calculated using the following formula:

$$
\mathrm{CAR}=\frac{\text { Total Capital }}{\text { ATMR }}
$$

CAR indicates the ability of a bank to cover the decrease in its assets resulting from the risky ones. Based on the stipulation issued by the Bank of Indonesia, the capital of a bank is made up of the core capital and complementary capital. It is also stipulated by the Bank of Indonesia that ATMR can be calculated based on the value of each post of assets in the bank's balance sheet multiplied by its risk value, and that it can also be calculated based on the value of each post of assets in the bank's administration account multiplied by its risk value.

\section{2) Assets (Productive Asset)}

An asset is an item which can be tangible and intangible and has a source and can be economically significant (Baridwan, 2004). It is a source controlled by a company resulting from any past event and can be economically significant in the future (Hanafi, 2003). In the circular issued by the Bank of Indonesia (Number 26/4/BPPP) it is stated that:

a) A productive asset is the investment of the funds of a bank in the form of credits, securities, the placement of funds in another bank and any accompaniment which is intended to obtain earnings.

b) The classified productive asset is the one which has the potential of generating earnings or incurring losses for a bank.

From what was described above it can be concluded that the productive asset refers to every tangible and intangible item and the source which a company has and can be significant and generate income in the future (Taufik, 2012). The quality of the productive asset is assessed based on the classification of collectability which is made up of: (a) being smooth, (b) needing a particular attention, (d) being less smooth, (d) being doubtful and (e) being bad (Suseno, 2003).

a) Being smooth

1) In time payment

2) Good account development

3) No payment arrear and in accordance with the credit requirement

b) Needing a particular attention

1) There are payment arrears for the principal or interest for 90 days.

2) Rarely experiencing overdraft

c) Less Smooth

1) The payment arrear for the principle or interest ranges from 90 to 120 days.

2) Overdrafts are frequently made in order to cover any operating losses and the shortage of the cash flow.

d) Being questionable

1) There are payment arrears for the principal and interest which exceed from 120 days to 180 days. 
2) Overdrafts are permanently made in order to cover the operating losses and the shortage of the cash flow.

e) Being bad

1) The payment arrears for the principal and or interest exceed 180 days. Based on the Bali Governor's Regulation dated 7 March 2003 Number 11 of 2013, the quality of Productive Asset is based on the following principles:

a) The ratio of the quality of the productive asset 'Rasio kualitas aktiva produktif (KAP)'. It is intended to assess the quality of the productive assets, namely the percentage of the comparison of the classified productive assets to the total productive assets as presented in the following formula:

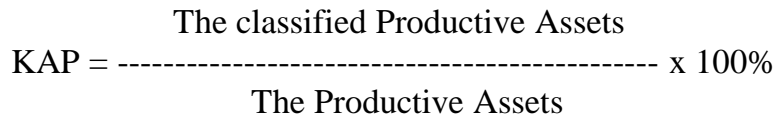

b) The Reserve Undecided Loan Ratio 'Rasio Cadangan Pinjaman Ragu-Ragu (CPRR)'. It is intended to assess whether CPRR is adequately prepared, namely the percentage of the comparison of the formed CPRR to the obligatorily-formed CPRR, as presented in the following formula.

$$
\begin{aligned}
& \text { The formed CPRR } \\
& \text { CPRR = ----------------------- x 100\% }
\end{aligned}
$$

\section{3) Management}

The management aspect can be assessed through the components of the general management and the risk management (Riyadi, 2000). Based on the Bali Governor's Regulation dated 7 March 2013 Number 11 of 2013 concerning the way of assessing how healthy an LPD is, the management can be assessed from two aspects as follows.

a) The general management, namely the assessment of the aspects of the general management which include the assessment of the strategy or target, structure, system and leadership.

b) The risk management, namely the assessment of the risk management which includes liquidity, the risk of the loans provided, the operating risk, legal risk, and the risk of the owner and management.

From what was described above, it can be concluded that management refers to an ability which the bank has to manage the aspects of the General Management and Risk Management based on the commitment already made. Kristina (2013) states that there are two formulas which can be used to assess the management factors. They are:

a. The General Management

The General Management $=$ the assessment of the strategy + structure + system + leadership

b. The Risk Management $=$ the assessment of the liquidity risk + credit risk + operating risk + legal risk + the risk of the ownership

\section{4) Earning}

Earning refers to the ability of a company to obtain profit through all the resources it has such as sales, cash, assets, capital (Hararap, 2004: 219). It is the 
ability of a bank to increase the profit it can obtain every period of time. It is used to measure the level of efficiency and profitability obtained by the bank (Kashmir, 2004: 49). It shows the comparison between profit and the asset or capital which generates profit (Riyanti, 2002). From what was defined above it can be concluded that earning is the ability of a company to generate profit from a number of capitals during a certain period of time. Based on the Bali Governor's Regulation dated 7 March 2013 Number 11 of 2013 concerning the way of assessing how healthy an LPD Unit is, earning can be measured using two ratios; they are:

a) Return on assets (ROA), the ratio of profit before tax to the average asset. ROA is calculated using the following formula:

$$
\begin{gathered}
\text { The Current Profit } \\
\text { The Average Asset }
\end{gathered}
$$

b) The Ratio of the Operating Expenses to the Earning Expenses 'Rasio Biaya Operasional dan Biaya Pendapatan (BOPO)' is the ratio of the operating expenses to the operating earnings. BOPO is calculated using the following formula.

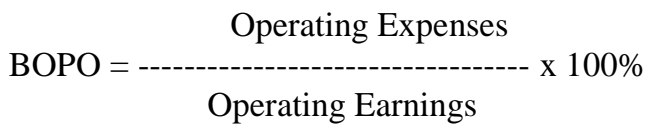

\section{5) Liquidity}

Liquidity is the ability of a company to pay immediately for its liabilities (Riyanto, 2001:25). It shows the company's ability to fulfill its short term liabilities to the creditor (Darminto and Rifka, 2002: 10). From what was defined above, it can be concluded that liquidity refers to the ability of a company to pay for its shortterm liabilities which should be immediately fulfilled. Based on the Bali Governor's Regulation dated 7 March 2013 Number 11 of 2013 concerning the way of assessing how healthy an LPD Unit is, the liquidity aspect can be assessed using two ratios; they are:

a) Ratio of Liquid Instrument

It is intended to assess the ability of an LPD unit to pay for its current liabilities, namely the percentage of the comparison between the liquid instruments to the current liabilities. The liquid instrument is calculated using the following formula:

$$
\begin{aligned}
& \text { Cash + Among the Bank's Assets }
\end{aligned}
$$

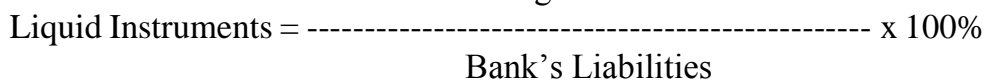

b) Loan to Deposit Ratio (LDR)

It is intended to assess the ratio loans provided to the funds received. The funds received are made up of:

1) Deposits and the society's savings

2) Loans from banks and other financial institutions

3) Core capital 
4) The capital obtained from loans/deposits

Based on the Bali Governor's Regulation dated on 7 March 2013 Number 11 of 2013, LDR is calculated using the following formula.

Loans provided

$$
\text { LDR = ----------------------- x 100\% }
$$

\section{RESEARCH METHODOLOGY \\ Research Design}

This present study is a descriptive quantitative one in which the financial statements are analyzed before they are tabulated in order to know whether the LPD Units are under the category of being healthy or not healthy. The descriptive study describes a variable or a phenomenon as it is. The time dimension used is time series and the study was carried out in a cross sectional manner. The aspects used to assess the level of the soundness of the LPD Units are as follows: (1) the capital with CAR ratio, (2) the assets with two ratios, namely KAP and CPRR, (3) Management, (4) Earnings with two ratios; they are ROA, and BOPO, and (5) Liquidity with two ratios; they are the liquid instrument and LDR.

\section{Subject and Object of the Study}

The subject of the study includes all the LPD Units in Gerokgak District, Buleleng Regency. The object of the study is how healthy the LPD Units in Gerokgak District are and includes the capital, asset, management, earnings and liquidity aspects.

\section{Data Type and Source}

The data used in this present study are (1) the quantitative data and (2) qualitative data.

1) Quantitative data

Quantitative data are the data which are in the form of numbers (Sugiyono, 2008: 12). In this present study the quantitative data used are the financial statements of all the LPD Units in Gerokgak District in 2015 and 2016.

2) Qualitative Data

The qualitative data refer to the data which are in the forms of words, sentences, schemes and pictures (Sugiyono, 2008: 12). In this present study the qualitative data are on the management aspect.

The data sources used in this present study are (1) the primary data, and (2) the secondary data.

1) The primary data are the data obtained from the primary source, which, in this study, were obtained through structured interviews in which the interviewees were Heads of all the LPD Units in Gerokgak Village. The data are in the form of the answers to the questions related to the general management aspect and risk management aspect.

2) The secondary data are the data directly obtained from mediating media (Indriantoro and Supomo, 2013: 147). In this present study the secondary data were obtained from the financial statements of the all the LPD Units in Gerokgak District and are related to the Capital, Asset, Earnings, and Liquidity aspects. 
The values of the component credit or the productive asset quality (KAP) factor are as follows:

1) $20 \%$ or more result of ratio is valued 0 .

2) Every $0.15 \%$ decrease starting from $20 \%$ is valued from 1 to 100

The value of the component credit or the productive asset quality factor 'faktor kualitas aktiva produktif (KAP) is presented in the following formula.

$$
\text { The KAP value }=\text {---------------- }
$$

b) The Reserve Undecided Loan Ratio 'Cadangan Pinjaman Ragu-ragu (CPRR) Based on the Bali Governor's Regulation dated 7 March 2013 Number 11 of 2013 the whether CPRR is adequately prepared or not can be assessed from the percentage of the comparison of the formed CPRR to the obligatorilyformed CPRR. The following formula can be used to identify the LPD's CPRR ratio.

$$
\begin{gathered}
\text { The formed CPRR } \\
\text { CPRR ratio = }- \text { The obligatorily }- \text { formed CPRR }
\end{gathered}
$$

The values of the component credit or the factor of the prepared reserve undecided loan 'cadangan pinjaman ragu-ragu (CPRR)' are as follows.

1) The 0 ratio is valued 0 .

2) Every $1 \%$ increase starting from 0 to 100 is valued 1 . The value of the component credit or the factor of CPRR is presented in the following formula.

\section{3) Management}

$$
\text { CPPR value }=\text { CPRR ratio } x 1
$$

According to Martono (2002), management can be seen from the quality of someone who knows what to do to educate his/her employees to settle any problem. In a management, what is assessed includes the capital management, the asset management, the general management, the rentability management, and the liquidity management. The general management aspect and risk management aspect should be assessed in order to be able to measure how healthy the LPD Units are. Based on the Bali Governor's regulation dated 7 March 2013 Number 11 of 2013 concerning how to assess how healthy an LPD is, the LPD's management should be assessed based on the questions and answers related to the general management and risk management. The assessment of the general management focuses on (a) the strategy/target, (b) the organizational structure, (c) the system, and (d) the leadership. The assessment of the risk management focuses on the following components: (a) the liquidity risk, (b) the credit risk, (c) the operating risk, (d) the legal risk, and (e) the risk of ownership. The credit value was calculated based on the results of the answers to the questions consisting of 25 questions related to management; each question was valued from 1 to 4 . Criterion $(0)=$ not or not at all intending to fulfill it; (1) not intending but having planned to fulfill it; (2) having been fulfilled but most not yet fulfilled; (3) having been fulfilled, but a few have not been; (4) having been fully fulfilled. The value of management credit was obtained by adding up the values provided to each question/question related to 
management; the maximum value was 100. Its contribution to the LPD's soundness was determined $10 \%$ or the value $\mathrm{x} 10 \%$.

\section{4) Earning}

According to Eka (2012), earning refers to the attempt made by a bank to generate profit. A bank is stated to be healthy if its rentability keeps improving. Earning can be assessed from two components; they are the return on asset (ROA) ratio and the operating expenses resulting from the operating earning 'biaya operasional terhadap pendapatan operasional (BOPO)'.

a) Return On Asset (ROA)

Based on the Bali Governor's Regulation dated 7 March 2013 Number 11 of 2013, the LPD's ability to generate earning from the average assets it has can be assessed using the following formula.

The earning currently earned

$$
\text { ROA = ------------ } \text { x 100\% }
$$

The values of the credit component or ROA factor are as follows.

1) 0 or negative ratio is valued 0 .

2) Every $0.025 \%$ increase from 0 is valued from 1 to 100 .

The value of the component credit or ROA factor is presented using the following formula.

$$
\text { The ROA value = ---------- }
$$

b) The operating expenditure resulting from the operating earning 'Biaya Operasional terhadap pendapatan operasional (BOPO)'.

Based on the Bali Governor's Regulation dated 7 March 2013 Number 11 of 2013, how efficient an LPD when it buys things or the percentage of the comparison of the operating expenses to the operating earning can be assessed as presented in the following formula.

$$
\begin{aligned}
& \text { The Operating Expenses } \\
& \text { BOPO ratio }=\text {----------------------- x 100\% }
\end{aligned}
$$

The values of the credit component or BOPO factor are as follows.

1) $100 \%$ or higher ratio is valued 0 .

2) Every $0.25 \%$ decrease from $100 \%$ is valued from 1 to 100 .

The value of the BOPO component credit is presented using the following formula.

$$
\text { BOPO ratio }=\text {------ } 0.25
$$

\section{5) Liquidity}

According to Eka (2012), liquidity refers to the ability to pay for liabilities that should be immediately paid for. The assessment of liquidity is made up of two components; they are liquid instrument ratio and the ratio of the loans provided to the funds received (LDR).

a) Liquid Instrument Ratio

Based on the Bali Governor's Regulation dated 7 March 2013 Number 11 of 2013, the LPD's ability to fulfill its current liabilities, namely the percentage 
of the comparison of the liquid instruments to the current liabilities can be assessed using the following formula.

$$
\text { The liquid instrument ratio }=\frac{\mathrm{Cash}+\mathrm{ABA}}{\mathrm{Current} \text { Liabilities }}
$$

The liquid instruments are made up of cash and the funds placed at LPD (the Inter-bank Assets) in the forms of clearing accounts and savings. The interbank assets in the forms of fixed deposits at the bank or other financial institutions to which a particular attention is paid are not taken into account. The current liabilities include the immediate liabilities (including payment for installments/loans provided by a bank or another financial institution), savings and fixed deposits. follows.

The value of the component credit or the liquid instrument factor is as

1) The ratio 0 is valued 0 and every $0.05 \%$ increase from 0 starting from 1 to 100 is added.

The value of the component credit of the liquid instrument is presented using the following formula.

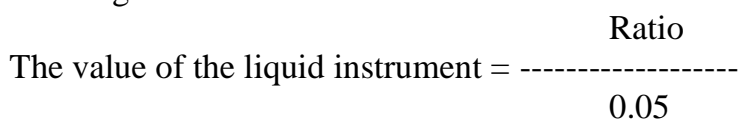

b) Loan to Deposit Ratio (LDR)

It is intended to assess the ratio of the loans provided to the funds received. The funds received are made up of.

1) The society's fixed deposits and savings.

2) The loans provided by another bank or financial institution.

3) The core capital.

4) The borrowed/deposited capital.

Based on the Bali Governor's regulation dated 7 March 2013 Number 11 of 2013, LDR is calculated using the following formula.

$$
\text { LDR ratio }=
$$

The values of the component credit or the LDR factor are as follows.

1) The credit value of $115 \%$ or more ratio is 0 .

2) For every $1 \%$ increase from the $115 \%$ ratio, starting from 4 to 100 is added to the credit value.

3) If the value $\leq 94.74 \%$, the value is automatically maximum.

The LDR component credit value is presented using the following formula.

The LDR value $=(115-$ Ratio $) \times 4$

How healthy an LPD is can be basically assessed using the qualitative approach to the five components which affect its condition and development as a financial institution. The five components are as follows (1) the capital, (2) the productive asset quality, (3) the management, (4) the earning, and (5) the liquidity. Such factors have several components which are valued in order to be able to determine the LPD's soundness as can be seen in Table 1 below. 
Table 1 The assessment of the LPD's soundness.

\begin{tabular}{|c|c|c|c|c|c|}
\hline \multicolumn{2}{|c|}{$\begin{array}{l}\text { THE ASSESSED } \\
\text { FACTORS }\end{array}$} & \multicolumn{3}{|c|}{ COMPONENTS } & \multirow{2}{*}{$\begin{array}{c}\text { VALUES } \\
25 \%\end{array}$} \\
\hline 1) & Capital & & $\begin{array}{l}\text { tal Adequacy Ratio } \\
\text { R) }\end{array}$ & $\begin{array}{l}\text { Percentage of Comparison of } \\
\text { the LPD's capital to Risk- } \\
\text { weighted Assets }\end{array}$ & \\
\hline \multirow[t]{2}{*}{ 2) } & $\begin{array}{l}\text { The } \\
\text { Productive } \\
\text { Asset Quality }\end{array}$ & a) & $\begin{array}{l}\text { The Productive Asset } \\
\text { Quality 'Kualitas Aktiva } \\
\text { Produktif (KAP)' }\end{array}$ & $\begin{array}{l}\text { The percentage of the } \\
\text { comparison of the classified } \\
\text { productive assets to the total } \\
\text { assets }\end{array}$ & $25 \%$ \\
\hline & & b) & $\begin{array}{l}\text { Reserve Undecided } \\
\text { Loans 'Cadangan } \\
\text { Pinjaman Ragu-ragu' }\end{array}$ & $\begin{array}{l}\text { The percentage of the } \\
\text { comparison of the formed } \\
\text { CPRR to the obligatorily- } \\
\text { formed CPRR }\end{array}$ & $10 \%$ \\
\hline 3) & $\begin{array}{l}\text { The } \\
\text { Management }\end{array}$ & \multicolumn{3}{|c|}{$\begin{array}{l}\text { Made up of } 25 \text { questions related to management, each is } \\
\text { valued between } 0 \text { until } 4\end{array}$} & $10 \%$ \\
\hline \multirow[t]{2}{*}{ 4) } & Earning & & ROA & $\begin{array}{l}\text { The percentage of the } \\
\text { comparison of earning to the } \\
\text { total assets }\end{array}$ & $10 \%$ \\
\hline & & b) & BOPO & $\begin{array}{l}\text { The percentage of the } \\
\text { comparison of costs to } \\
\text { income }\end{array}$ & $10 \%$ \\
\hline & Liquidity & a) & Liquid Instruments & $\begin{array}{l}\text { The percentage of the } \\
\text { comparison of the liquid } \\
\text { instruments to current } \\
\text { liabilities }\end{array}$ & $5 \%$ \\
\hline & & & LDR & $\begin{array}{l}\text { The percentage of the } \\
\text { comparison of liabilities to } \\
\text { fund received }\end{array}$ & $5 \%$ \\
\hline
\end{tabular}

Source: Based on the Bali Governor's Regulation dated 7 March 2013 Number 11 of 2013 concerning the way of assessing how healthy an LPD is.

The stages through which the LPD's soundness is assessed are as follows.

1) Checking the validity of the LPD's financial statement and information on its management.

2) Calculating the ratio of each factor or component assessed.

3) Calculating the credit value of each factor or component based on the criteria or indicators of assessment.

4) Calculating the value of the contribution of each component based on the value used to determine whether LPD is healthy or not.

5) Calculating the value of soundness by adding up the value of the contribution of all the components determining whether LPD is healthy or not. The value of soundness is used to determine the criteria that it should fulfill in order to be under the category of being healthy. The criteria are determined using the following values. 
Table 2 The Criteria determining that LPD is healthy are presented in the following table.

\begin{tabular}{cl}
\hline $\begin{array}{c}\text { Total Values of Being } \\
\text { Healthy }\end{array}$ & \multicolumn{1}{c}{ Criteria } \\
\hline $81-100$ & Being healthy \\
\hline $66-<81$ & Being healthy enough \\
\hline $51-<66$ & Being less healthy \\
\hline $0-<51$ & Being unhealthy \\
\hline
\end{tabular}

Source: Based on the Bali Governor's Regulation dated 7 March 2013 Number 11 of 2013 concerning the way of assessing whether an LPD is healthy or not.

\section{RESULTS AND DISCUSSION}

The CAMEL analysis is the technique used to identify the level of the soundness of all the LPD Units in Gerogak District. CAMEL analysis includes the analysis of Capital, Asset, Management, Earning, and Liquidity. In this case, the study of Capital, Asset, Earning and Liquidity was used as the realization of the financial statements for the last two years, namely from 2015 to 2016 . The management aspect was assessed through structured interviews in which the general management aspect and the risk management aspect were assessed. The CAMEL analysis was used to analyze how healthy the LPD Units in Gerokgak District were from 2015 to 2016.

\section{Capital}

Based on the result of the study already carried out, it can be stated that among the 13 LPD Units in Gerokgak District, eight underwent a rise in their CAR. They were the LPD Unit at Banyu Poh, the LPD Unit at Celukan Bawang, the LPD Unit at Musi, the LPD Unit at Pemuteran, the LPD Unit at Pengulon, the LPD Unit at Sanggalangit, the LPD Unit at Sumberkima, and the LPD Unit at Tukad Sumaga. The capital they had and their stability in preparing the minimum capital which could minimize the funds used contributed to their improved CAR. The LPD Units which underwent a decrease in their CAR were the LPD Unit at Gerokgak, the LPD Unit at Patas, the LPD Unit at Pejarakan, the LPD Unit at Penyabangan, and the one at Tinga-Tinga. The decrease resulted from the attempt to extend their businesses and the increased financing, causing the percentage of the capital they had to go down. The increased CAR caused the component credit value to increase. This was undergone by the LPD Unit at Banyu Poh, the LPD Unit at Celukan Bawan, the LPD Unit at Musi, the LPD Unit at Pemuteran, the LPD Unit at Pengulon, the LPD Unit at Sanggalangit, the LPD Unit at Sumberkima, and the LPD Unit at Tukad Sumaga. Those which underwent the fall in the component credit value were the LPD Unit at Gerokgak, the LPD Unit at Patas, the LPD Unit at Pejarakan, the LPD Unit at Penyabangan, and the LPD Unit at Tinga-Tinga. The rise and fall in the component credit value highly contribute to whether an LPD is healthy or not. Among the 13 LPD Units, the LPD Unit at Gerokgak, the LPD Unit at Musi, the LPD Unit at Patas, the LPD Unit at Pejarakan, the LPD Unit at Pengulon, the LPD Unit at Penyabangan, the LPD Unit at Sanggalangit, and the one at Tukad Sumaga fulfilled the criterion of being healthy from 2015 to 2016 . The one which was under the category of being healthy enough from 2015 to 2016 was LPD Sumberkima. Those which were under the category of being unhealthy from 2015 to 2016 were the LPD Unit at Pemuteran and the one at Tinga-Tinga. 


\section{Assets}

In regard to the productive assets, there were two components which were assessed; they were the Productive Asset Quality Ratio 'Rasio Kualitas Aktiva Produktif (KAP) and the Reserve Undecided Loans 'Rasio Cadangan Pinjaman Ragu-ragu (CPRR).

a. The Productive Asset Quality Ratio (KAP)

From the result showing the level of the soundness of all the LPD Units in Gerokgak District, Buleleng Regency from the asset aspect using the KAP ratio, it can be explained that among the 13 LPD Units, nine were getting better in regard to their KAP ratio. They were the LPD Unit at Banyu Poh, the LPD Unit at Celukan Bawang, the LPD Unit at Patas, the LPD Unit at Pejarakan, the LPD Unit at Pemuteran, the LPD Unit at Penyabangan, the LPD Unit at Pengulon, the LPD Unit at Sanggalangit and the LPD Unit at Tukad Sumaga. The increase in the KAP ratio resulted from the productive assets which were adjusted to the productive asset management. Those of which the KAP ratio went down were the LPD Unit at Gerokgak, the LPD at Musi, the LPD at Sumberkima, and the LPD Unit at TingaTinga. The decrease in the KAP ratio resulted from a condition in which the total productive assets rose higher than the total classified productive assets. The rise in the KAP ratio caused the component credit value to go down. The LPD Units of which the component credit value went down were the LPD Unit at Banyu Poh, the LPD Unit at Celukan Bawang, the LPD Unit at Patas, the LPD Unit at Pejarakan, the LPD Unit at Pemuteran, the LPD Unit at Penyabangan, the LPD Unit at Pengulon, the LPD Unit at Sanggalangit and the LPD Unit at Tukad Sumaga. The LPD Units of which the component credit value rose were the LPD Unit at Gerokgak, the LPD Unit at Musi, the LPD Unit at Sumberkima, and the LPD Unit at Tinga-Tinga. The rise and fall in the component credit value strongly determine whether an LPD is healthy or not. The LPD Units which were categorized as being healthy from 2015 to 2016 were the LPD Unit at Celukan Bawang, the LPD Unit at Gerokgak, the LPD Unit at Musi, the LPD Unit at Patas, the LPD Unit at Pejarakan, the LPD Unit at Pemuteran, the LPD Unit at Pengulon, the LPD Unit at Sumberkima, the LPD Unit at Tinga-Tinga and the LPD Unit at Tukad Sumberkima. The LPD Unit which was categorized as being healthy enough from 2015 to 2016 was the LPD Unit at Sumberkima. The ones which were categorized as being not healthy were the LPD Unit at Pemuteran and the LPD Unit at Tinga-Tinga.

b. The Reserve Undecided Loan "Rasio Cadangan Pinjaman Ragu-Ragu (CPRR)"

CPRR is used to assess the adequacy of CPRR availability, namely the percentage of the comparison of the formed CPRR to the obligatorily-formed CPRR. From the result showing the level of the soundness of all the LPD Units in Gerogak District, Buleleng Regency, it can be explained that among the 13 Units, 9 underwent a rise in the CPRR ratio; they were the LPD Unit at Celukan Bawang, the LPD Unit at Musi, the LPD Unit at Musi, the LPD Unit at Patas, the LPD Unit at Pemuteran, the LPD Unit at Pengulon, the LPD Unit at Penyabangan, the LPD Unit at Sanggalangit, the LPD Unit at Sumberkima, and the LPD Unit at Tingatinga. Those which underwent a rise in the CPRR ratio were the LPD Unit at Banyu Poh, the LPD Unit at Gerokgak, the LPD Unit at Pejarakan, and the LPD Unit at Tukad Sumaga. Those which underwent a drop in the CPRR ratio were the LPD Unit at Banyu Poh, the LPD Unit at Gerokgak, the LPD Unit at Tukad Sumaga. 
The rise in the CPRR ratio caused the component credit value to go up. Those which underwent an increase in the component credit value were the LPD Unit at Celukan Bawang, the LPD Unit at Musi, the LPD Unit at Patas, the LPD Unit at Pemuteran, the LPD Unit at Pengulon, the LPD Unit at Penyabangan, the LPD Unit at Sanggalangit, the LPD Unit at Sumberkima, and the one at Tinga-Tinga. Those who underwent a fall in the component credit value were the LPD Unit at Banyu Poh, the LPD Unit at Gerokgak, the LPD Unit at Pejarakan, and the LPD Unit at Tukad Sumaga. The increase and fall in the component credit value strongly determines whether an LPD is healthy or not. The LPD Units which were categorized as being healthy from 2015 to 2016 were the LPD Unit at Musi, the LPD Unit at Patas, the LPD Unit at Pejarakan, the LPD Unit at Pemuteran, the LPD Unit at Sanggalangit, the LPD Unit at Sumberkima, the LPD Unit at Tinga-Tinga and the LPD Unit at Tukad Sumaga. In 2015 the LPD Unit at Celukan Bawang was under the category of being less healthy; however, in 2016 it was under the category of being healthy. Those which were under the category of being not healthy from 2015 to 2016 were the LPD Unit at Banyu Poh, the LPD Unit at Pengulon, and the LPD Unit at Penyabangan.

\section{c. Management}

The assessment of the general management aspect and the risk management aspect was used to measure whether an LPD is healthy or not. In this present study, the management aspect was assessed using the structured interview in which the interviewees were Heads of all the LPD Units in Gerokgak District, Buleleng Regency. From the result showing the level of the soundness of the LPD Units in Gerokgak District, Buleleng Regency, it can be explained that among the 13 LPD Units, there was not any change in value in regard to the general management aspect and the risk management aspect from 2015 to 2016. The cause was that there had not been any change in management. From 2015 to 2016 the management aspect of all the Units was under the category of being healthy, as the total value of the general management and risk management was under the category of being healthy, namely 81 points.

\section{d. Earning}

There were two ratios which were used to assess the level of the soundness of the LPD Units. They were Return on Asset (ROA) ratio and BOPO ratio.

a. Return on Asset (ROA) Ratio

The result showing the level of the soundness of all the LPD Units in Gerokgak District, Buleleng Regency, using the ROA ratio can be explained as follows. Among the 13 LPD Units in Gerokgak District, Buleleng Regency, 8 underwent an increase in the ROA ratio. They were the LPD Unit at Banyu Poh, the LPD Unit at Celukan Bawang, the LPD Unit at Musi, the LPD Unit at Patas, the LPD Unit at Pemuteran, the LPD Unit at Pengulon, the LPD Unit at Sanggalangit, and the LPD Unit at Tinga-Tinga. The increase in the ROA ratio resulted from the fact that the average productive assets and the operating earnings were distributed based on the profit-sharing principle of which the percentage was higher than the increase in the operating earnings. The LPD Units which underwent a fall in the ROA ratio were the LPD Unit at Gerokgak, the LPD Unit at Pejarakan, the LPD Unit at Penyabangan, the LPD Unit at Sumberkima, and the LPD Unit at Tukad Sumaga. The decrease in the ROA ratio resulted from the fact that the operating earnings earned were lower than the increase in the average productive assets. The rise in the ROA ratio caused the component credit value to increase. The LPD Units which 
underwent an increase in the component credit value were the LPD Unit at Banyu Poh, the LPD Unit at Celukan Bawang, the LPD Unit at Musi, the LPD Unit at Patas, the LPD Unit at Pemuteran, the LPD Unit at Pengulon, the LPD Unit at Sanggalangit, and the LPD Unit at Tinga-Tinga. Those which underwent a fall in the component credit value were the LPD Unit at Gerokgak, the LPD Unit at Pejarakan, the LPD Unit at Penyabangan, the LPD Unit at Sumberkima, and the LPD Unit at Tukad Sumaga. The rice and fall in the component credit value strongly determines whether an LPD is healthy or not. The LPD Units which were under the category of being healthy from 2015 to 2016 were the LPD Unit at Celukan Bawang, the LPD Unit at Gerokgak, the LPD Unit at Musi, the LPD Unit at Patas, the LPD Unit at Pejarakan, the LPD Unit at Pemuteran, the LPD Unit at Penyabangan, the LPD Unit at Sanggalangit, the LPD Unit at Tinga-Tinga and the LPD Unit at Tukad Sumaga. The LPD Unit which was under the category of being healthy in 2015 was the one at Sumberkima. The ones which were under the category of being less healthy in 2016 were the LPD Unit at Banyu Poh and the LPD Unit at Sumberkima. The one which was under the category of being healthy enough from 2015 to 2016 was the LPD Unit at Pengulon. And the one which was under the category of being not healthy in 2015 was the LPD Unit at Banyu Poh.

b. The Operating Expenses of the Operating Earnings 'Biaya Operasional terhadap Pendapatan Operasional (BOPO)'

The result showing the level of the soundness of all the LPD Units in Gerokgak District, Buleleng Regency using the BOPO ratio can be explained as follows. Among the 13 LPD Units in Gerokgak District, nine underwent an increase in the BOPO ratio. They were the LPD Unit at Banyu Poh, the LPD Unit at Celukan Bawang, the LPD Unit at Patas, the LPD Unit at Pejarakan, the LPD Unit at Pengulon, the LPD Unit at Penyabangan, the LPD Unit at Sanggalangit, the LPD Unit at Sumberkima, and the LPD Unit at Tukad Sumaga. The increase in the BOPO ratio resulted from the fact the operating expenses were higher than the operating earnings. The LPD Units which underwent a decrease in the BOPO ratio were the LPD Unit at Gerokgak, the LPD Unit at Musi, the LPD Unit at Pemuteran, and the LPD Unit at Tinga-Tinga. The decrease in the BOPO ratio resulted from the increase in the operating expenses which were higher than the operating expenses. The rise in the BOPO ratio caused the component credit value to decrease. The LPD Units which underwent an increase in the component credit value were the LPD Unit at Banyu Poh, the LPD Unit at Celukan Bawang, the LPD Unit at Patas, the LPD Unit at Pejarakan, the LPD Unit at Pengulon, the LPD Unit at Penyabangan, the LPD Unit at Sanggalangit, the LPD Unit at Sumberkima, and the LPD Unit at Tukad Sumaga. The LPD units which underwent a dip in the component credit value were the LPD Unit at Gerokgak, the LPD Unit at Musi, the LPD Unit at Pemuteran, and the LPD Unit at Tinga-Tinga. The fall and rise in the component credit value strongly determines whether an LPD is healthy or not. The LPD Units which were under the category of being healthy from 2015 to 2016 were the LPD Unit Celukan Bawang, the LPD Unit at Gerokgak, the LPD Unit at Patas, the LPD Unit at Pejarakan, the LPD Unit at Pengulon, the LPD Unit at Penyabangan, the LPD Unit at Sanggalangit, the LPD Unit at Tinga-Tinga and the LPD Unit at Tukad Sumaga. The one which was under the category of being less healthy from 2015 to 2016 was the LPD Unit at Pemuteran. The one which was under the category of being less healthy in 2016 was the LPD Unit at Musi. The one which was under the category of being healthy enough from 2015 to 2016 was 
the LPD Unit at Sumberkima, the one which was under the category of being not healthy in 2015 was the LPD Unit at Musi, and the one which was under the category of being not healthy from 2015 to 2016 was the LPD Unit at Banyu Poh.

\section{e. Liquidity}

From the liquidity aspect there were two ratios which were used to measure how healthy the LPD Units in Gerokgak District were. They were the Liquid Instrument ratio and the Loan to Deposit Ratio (LDR); each can be explained as follows.

a. The Liquid Instrument Ratio

From the result showing the level of the soundness of the LPD Units in Gerokgak District, Buleleng Regency, using the liquid instrument ratio, it can be explained as follows. Among the 13 LPD Units in Gerokgak District, the ones at Sumberkima and Tukad Sumaga showed an increase in the liquid instrument ratio, resulting from the fact that the liquid instruments used in their current liabilities went up. The ones showing a decrease in the liquid instruments were the LPD Unit at Banyu Poh, the LPD Unit at Celukan Bawang, the LPD Unit at Patas, the LPD Unit at Pejarakan, the LPD Unit at Pengulon, the LPD Unit at Penyabangan, the LPD Unit at Sanggalangit, the LPD Unit at Gerokgak, the LPD Unit at Pemuteran, and the one at Tinga-Tinga, resulting from the fact that the liquid instruments used to pay off the short-term savings went down if compared to their ability to guarantee their current liabilities using the liquid instruments they had. The rise in the liquid instrument ratio caused the component credit value to go up. The LPD Units which underwent an increase in the component credit value included the LPD Unit at Musi, the LPD Unit at Sumberkima, and the one at Tukad Sumaga. The ones which underwent a fall in the component credit value included the LPD Unit at Banyu Poh, the LPD Unit at Celukan Bawang, the LPD Unit at Patas, the LPD Unit at Pejarakan, the LPD Unit at Pengulon, the LPD Unit at Penyabangan, the LPD Unit at Sanggalangit, the LPD Unit at Gerokgak, the LPD Unit at Pemuteran, and the one at Tinga-Tinga. The rise and fall in the component credit value strongly determine whether an LPD is healthy or not. Viewed from the earning aspect in general and the liquid ratio instrument in particular, the LPD Units in Gerokgak District were under the category of being healthy from 2015 to 2016 as their component credit value was 100 points, meaning that they reached the maximum limit to be categorized as being healthy.

b. LDR

LDR is used to assess the ratio of the loans provided to the funds received. The result showing the level of the soundness of the LPD Units in Gerokgak District, Buleleng Regency using LDR can be explained as follows. Among the 13 LPD Units in Gerokgak District, 11 underwent an increase in LDR. They were the LPD Unit at Banyu Poh, the LPD Unit at Celukan Bawang, the LPD Unit at Patas, the LPD Unit at Pejarakan, the LPD Unit at Pengulon, the LPD Unit at Penyabangan, the LPD Unit at Sanggalangit, the LPD Unit at Gerokgak, the LPD Unit at Pemuteran, the LPD Unit at Tinga-Tinga and the one at Tukad Sumaga, resulting from the loans distributed to the society exceeded the increase in the amount of the funds received. The LPD Units which underwent a fall in LDR were the LPD Unit at Musi and the one at LPD Sumberkima, resulting from the fact that the increase in the formed liquidity was smaller than it should have been. The increase in LDR caused the component credit value to go down. The LPD Units which underwent the rise in the component credit value included the LPD Unit at Banyu Poh, the 
LPD Unit at Celukan Bawang, the LPD Unit at Patas, the LPD Unit at Pejarakan, the LPD Unit at Pengulon, the LPD Unit at Penyabangan, the LPD Unit at Sanggalangit, the LPD Unit at Gerokgak, the LPD Unit at Pemuteran, and the ones at Ting-Tinga and Tukad Sumaga. The ones which underwent a fall in the component credit value included the LPD Unit at Sumberkima and the one at Sumberkima. The fall and rise in the component credit value strongly determines whether an LPD is healthy or not. Viewed from LDR, the LPD Units in Gerokgak District were under the category of being healthy from 2015 to 2016, as their component credit value was 100 points, meaning that they reached the maximum value of being under the category of being healthy.

\section{DISCUSSION}

The technique used to analyze the level of the soundness of all the LPD Units in Gerokgak District, Buleleng Regency was CAMEL, which includes Capital, Asset, Management, Earning, and Liquidity. In this case, the financial statements for the last two years, namely 2015 and 2016, were assessed from the Capital, Asset, Earning, and Liquidity aspects. The management aspect was assessed through the general management aspect and risk management aspect and the information needed for this was obtained through the structured interview. The result of the study is in accordance with the result of the study carried out by Mei (2015), in which it was stated that the CAMEL analysis was used to assess the level of the soundness of an LPD. The CAMEL aspects which were used to analyze the level of the soundness of all the LPD Units in Gerokgak District from 2015 to 2016 can be explained as follows.

From the Capital aspect, it could be identified that among 13 LPD Units spreading in Gerokgak District, eight were under the category of being healthy from 2015 to 2016. They were the LPD Unit at Banyu Poh, the LPD Unit at Gerokgak, the LPD Unit at Musi, the LPD Unit at Patas, the LPD Unit at Pengulon, the LPD Unit at Penyabangan, the LPD Unit at Sanggalangit, and the one at Tukad Sumaga, as the final credit value they achieved from the capital aspect reached the maximum value, ranging from 81 to 100 , fulfilling the criterion of being healthy. The CAR shown by all the LPD Units in Gerokgak District, Buleleng Regency, fulfilled the criterion of being healthy. The result of the study supports the result of the study conducted by Mei Budiyani (2015), in which it was found that almost all the capital aspects fulfilled the criterion of being healthy.

From the Asset aspect especially the KAP ratio, 10 among 13 the LPD Units spreading in Gerokgak District in 2016 were under the criterion of being healthy. They were the LPD Unit at Celukan Bawang, the LPD Unit at Gerokgak, the LPD Unit at Musi, the LPD Unit at Patas, the LPD Unit at Pejarakan, the LPD Unit at Pemuteran, the LPD Unit at Sanggalangit, the LPD Unit at Sumberkima, the LPD Unit at Tinga-Tinga, and the one at Tukad Sumaga, resulting from the fact that the KAP ratio obtained fulfilled the criterion being healthy, namely ranging from 81 to 100. Almost all the Asset aspects showed that the LPD Units spreading in Gerokgak District, Buleleng Regency, fulfilled the criterion of being healthy.

The CPRR ratio showed that among the 13 LPD Units spreading in Gerokgak District, 7 fulfilled the criterion of being healthy from 2015 to 2016. They were the LPD Unit at Musi, the LPD Unit at Patas, the LPD Unit at Pejarakan, the LPD Unit at Pemuteran, the LPD Unit at Sanggalangit, the LPD Unit at Sumberkima, the 
LPD Unit at Tinga-Tinga, and the one at Tukad Sumaga, resulting from the fact that the final credit value, if viewed from the KAP ratio and CPRR ratio, they achieved ranged from 81 to 100 points, meaning that they reached the maximum value to fulfill the criterion of being healthy. From the CPRR ratio, all the LPD Units in Gerokgrak District, Buleleng Regency, were under the criterion of being healthy. The result of the study supports the result of the study conducted by Komang Mei Budiyani (2015).

From the general management aspect and risk management aspect, all the LPD Units spreading in Gerokgak District were under the category of being healthy from 2015 to 2016, resulting from the fact that they achieved the maximum value, ranging from 81 to 100 points. The result of the study supports the result of the study performed by Luh Putu Kristina Wati (2013).

In the Earning aspect, there were two ratios assessed; they were the ROA ratio and BOPO ratio. From the ROA ratio produced by the 13 LPD Units in Gerokgak District from 2015 to 2016, 9 were under the criterion of being healthy; they were the LPD Unit at Celukan Bawang, the LPD Unit at Gerokgak, the LPD Unit at Musi, the LPD Unit at Patas, the LPD Unit at Pejarakan, the LPD Unit at Penyabangan, the LPD Unit at Sanggalangit, the LPD Unit at Tinga-Tinga, and the LPD Unit at Tukad Sumaga, as the ROA ratio they produced ranged from 81 to 100 points, indicating that they were under the criterion of being healthy.

From the BOPO ratio produced by the 13 LPD Units spreading in Gerokgak District from 2015 to 2016, 9 were under the criterion of being healthy; they were the LPD Unit at Celukan Bawang, the LPD Unit at Gerokgak, the LPD Unit at Patas, the LPD Unit at Pejarakan, the LPD Unit at Pengulon, the LPD Unit at Penyabangan, the LPD Unit at Sanggalangit, the LPD Unit at Tinga-Tinga, and the one at Tukad Sumaga as the final credit value they produced from the ROA and BOPO ratios ranged from 81 to 100 points, indicating that they were under the category of being healthy. Most the Earning aspects, namely the ROA and BOPO ratios, showed that all the LPD Units spreading in Gerokgak District were under the criterion of being healthy. The result of the present study supports the result of the study carried out by Komang Mei Budiyani (2015).

From the liquidity aspect, there were two ratios assessed; they were the Liquid Instrument ratio and LDR, which showed that all the LPD Units spreading in Gerokgak District were under the criterion of being healthy from 2015 to 2016, as their credit value remained 5, meaning that their component credit value reached the maximum value, namely 100 points.

From the LDR produced by the 13 LPD Units spreading in Gerokgak District from 2015 to 2016, it could be stated that they were all under the category of being healthy, as their credit value remained 5, meaning that their component credit value reached the maximum value, namely 100 points. The result of the study supports the result of the study carried out by Komang Mei Budiyani (2005).

Viewed from the final credit value, the LPD Units which were under the criterion of being healthy from 2015 to 2016 were the LPD Unit at Gerokgak, the LPD Unit at Musi, the LPD Unit at Patas, the LPD Unit at Pejarakan, the LPD Unit at Pengulon, the LPD Unit at Sanggalangit, the LPD Unit at Sumberkima, the LPD Unit at Tinga-Tinga, and the one at Tukad Sumaga. Those who were under the criterion of being healthy enough from 2015 to 2016 were the LPD Unit at Pemuteran and the one at Penyabangan. The one which was under the criterion of being healthy enough in 2015 was the LPD Unit at Celukan Bawang, and the one 
which was under the criterion of being healthy enough in 2016 was the LPD Unit at Banyu Poh. The one which was under categorized as being less healthy in 2015 was the LPD Unit at Banyu Poh. The result of the present study supports the result of the study carried out by Komang Mei Budiyani (2015). She also employed the CAMEL analysis to identify which LPD Units were healthy in 2015 and 2016.

\section{CONCLUSIONS}

Based on the analysis of the level of the soundness of all the LPD Units in Gerokgak District, Buleleng Regency from 2015 to 2016, several conclusions can be drawn as follows.

1) In 2015 the LPD Units spreading in Gerokgak District, Buleleng Regency were under the criterion of being healthy as the average CAMEL credit value they obtained was higher than 81 (the maximum limit of being healthy), as indicated by the CAMEL credit value in 2015, namely 86.48 points.

2) In 2016 they were also under the criterion of being healthy as the average CAMEL credit value obtained was higher than 81 (the maximum limit of being healthy), as indicated by the CAMEL credit value in 2016, namely 88.72 points.

\section{References}

Anggraeni, O. (2011). Penilaian Tingkat Kesehatan Bank dengan Menggunakan Metode CAMEL pada PT Bank Pembangunan Daerah Jawa Tengah Tahun 2006-2009. [Skripsi]. Jurusan Akuntansi, Fakultas Ekonomi, Universitas Diponegoro.

Ayu Ita Purnama Yanti, L. Analisis Tingkat Kesehatan Bank Perkreditan Rakyat Dengan Menggunakan Metode CAMEL (Studi Kasus Seluruh BPR di Kecamatan Buleleng Periode 2010-2012) [Skripsi]. Jurusan Manajemen, Fakultas Ekonomi dan Bisnis, Universitas Pendidikan Ganesha.

Azizati, N. (2010). Analisis Kinerja Keuangan Bank pada PT. Bank Perkreditan Desa (BPR) Jateng periode 2006-2008. [Skripsi]. Jurusan Akuntansi, Fakultas Ekonomi, Universitas Sebelas Maret Surakarta.

Budi Utami, S. (2015). Perbandingan Analisis CAMELS dan RGEC Dalam Menilai Tingkat Kesehatan Bank Pada Unit Usaha Syariah Milik Pemerintah (Studi Kasus: PT BANK NEGARA INDONESIA, TBK Tahun 2012-2013. [Skripsi]. Jurusan Akuntansi, Fakultas Ekonomi,Universitas Yogyakarta.

Ghulam Ajc, R. Analisis Lapran Keuangan Pada PT. Bank Pembangunan Daerah Sulawesi Selatan”. Makasar: Universitas Hasanudin.

Hanafi, M. M. (2003). Analisis Laporan Keuangan. Yogyakarta: UPP AMK YKPN. 
Harahap, S. S. (2004). Akuntansi Aktiva Tetap, Edisi Ketiga. Jakarta: PT. Raja Grafindo.

Ikatan Akuntan Indonesia. (2009). Standar Akuntansi Keuangan per 1 Juli 2009. Jakarta: Salemba Empat.

Jumingan. (2006). Analisis Laporan Keuangan. Cetakan Pertama. Jakarta. Bumi Aksara.

Karya Utama, I. M. (2012). Jurnal Analisis Camel: Penilaian Tingkat Kesehatan Bank yang Terdaftar di Bursa Efek Indonesia. Fakultas Ekonomi. Universitas Udayana.

Kristina Wati, L. P. (2013). Analisis Tingkat Kesehatan Bank Ditinjau Dari Faktor CAMEL(Capital, Asset, Management, Earning, Liquidity) Pada Bank BPD Bali Cabang Negara Kabupaten Jembrana Tahun 2008-2012. [Skripsi] (Diterbitkan). Jurusan Manajemen. Universitas Pendidikan Ganesha Singaraja.

Kasmir. (2002). Analisis Laporan Keuangan. Jakarta: Rajawali.

Mei Budiyani, K. (2015). Analisis CAMEL untuk Menilai Tingkat Kesehatan LPD Se-Kecamatan Tejakula Tahun 2013-2014. Jurnal. Jurusan S1 Akuntansi, Fakultas Ekonomi dan Bisnis, Universitas Pendidikan Ganesha.

Perturan Gubernur Bali Tanggal 7 Maret 2013 Nomor 11 Tahun 2013 tetang Tata Cara Penilaian LPD.

Puji, E. (2012). Analisis Penilaian Tingkat Kesehatan Bank Pada PT.Bank Muamalat Syariah, Tbk Cabang Denpasar. Fakultas Ekonomi. Universitas Udayana.

Rusmala Dewi S, M. (2011). Analisis Kinerja Kesehatan LPD dan Pengaruhnya terhadap Pertumbuhan Aset LPD Kecamatan Mengwi, Laporan hasil penelitian Fakultas Ekonomi Universitas Udayana. Sudirman. 2000. Manajemen Perbankan”. Edisi pertama. Denpasar: PT. Balai Pustaka.

Siamat, D. (1995). Manajemen Lembaga Keuangan. Jakarta: Fakultas Ekonomi Universitas Indonesia.

Soemarso. (2004). Akuntansi Suatu Pengantar. Jakarta: Salemba Empat.

Sugiyono. (2008). Metode Penelitian Bisnis (Pendekatan Kuantitatif, Kualitatif dan $R \& D)$. Bandung: Alfabeta.

Sundjaya., \& Barlian. Laporan Keuangan. Tersedia pada http://www.Jurnal.sdm.blogspot.com (diakses tanggal 3 November 2015). 
Suseno, A. P. (2003). Sistem Dan Lembaga Kebijakan Perbankan Di Indonesia. Jakarta: Pusat Pendidikan Dan Studi Kebanksentralan (PPSK) Bank Indonesia.

Susi Yuli Wahyuningsih, Ni Luh Putu. 2006. Analisis Tingkat Kesehatan Lembaga Perkreditan Desa (LPD) Desa Pakraman Pecatu Kecamatan Kuta Selatan Kabupaten Badung. [Skripsi]. Fakultas Ekonomi universitas Udayana Denpadar.

Susilowati, I. A. P. (2007). Analisis Kinerja Keuangan Lembaga Perkreditan Desa (LPD) di Kecamatan Ubud Kabupaten Gianyar Periode 2005 dan 2006. [Skripsi]. Fakultas Ekonomi Universitas Udayana Denpadar.

Taufik, D. (2012). Analisis Penilaian Tingkat Kesehatan BPR Hasa Mitra Dengan Metode CAMEL (Periode 2006-2010). [Skripsi]. Jurusan Manajemen, Fakultas Ekonomi dan Bisnis, Universitas Hasanuddin, Makasar.

Widhisudartha. (2013). Metode Penelitian. Tersedia pada http://www.wildawilda.wordpress.com/2011/02/25/ (diakses pada 3 November 2015). 